\title{
PARTIAL AMINO ACID SEQUENCES OF $\alpha$-AMYLASE ISOZYMES FROM BARLEY MALT
}

\author{
by \\ BIRTE SVENSSON", JOHN MUNDY', RICHARD M. GIBSON", and IB SVENDSEN" \\ "Department of Chemistry, Carlsberg Laboratory, \\ and \\ ${ }^{27}$ Department of Biotechnology, Carlsberg Research Laboratory, \\ Gl. Carlsberg Vej 10, DK-2500 Copenhagen Valby
}

Keywords: Isoelectric focusing, hydroxylamine, cyanogen bromide, reverse phase HPLC, peptide sequencing.

\begin{abstract}
Barley malt $\alpha$-amylases 1 and 2 , the low and high $\mathrm{pI}$ isozymes, respectively, were isolated and characterized by partial amino acid sequencing. The $\mathrm{NH}_{2}$-terminal sequence of $\alpha$-amylase 1 and the sequence of a peptide fragment of this protein obtained by cleavage with hydroxylamine matched the primary structure previously deduced from the nucleotide sequence of a barley $a$-amylase cDNA clone. In distinction to $\alpha$-amylase 1 , the homologous protein $\alpha$-amylase 2 had a blocked $\mathrm{NH}_{2}$-terminus, presumably a pyroglutamic acid residue. Sequenced peptide fragments from $\alpha$-amylase 2 matched the amino acid sequence previously derived from a cDNA clone corresponding to a barley $\alpha$-amylase different from $\alpha$-amylase 1 .
\end{abstract}

\section{INTRODUCTION}

Barley aleurone cells synthesize two groups of $\alpha$-amylase isozymes characterized by their different isoelectric points $(3,5,7,12,29)$. Both of these groups, called $\alpha$-amylase 1 and $\alpha$-amylase 2 , consist of proteins coded for by multigene families $(1,18,21)$. Nucleotide sequences of cloned cDNAs corresponding to $\alpha$-amylases from each group have recently been published by ROGERS and MILlimaN (20) and CHANDLER et al. (4). The proteins corresponding to these clones have homologous amino acid sequences diverging by approx. $23 \%$. However, multiple forms within each group of the $\alpha$-amy- lases 1 and 2 have been suggested to possess nearly identical primary structures $(3,7)$.

The present report describes the isolation of $\alpha$-amylase isozymes from barley malt and their characterization by partial amino acid sequencing. Our results demonstrate that a preparation of the low pI isozyme, here called $\alpha$-amylase 1 , corresponds to the sequenced, full-length cDNA clone E of Rogers and Milliman (20) while $\alpha$-amylase 2 , the high $\mathrm{pl}$ isozyme, represents a homologous, recently published partial-length cDNA clone pHV19 described by CHANDLER et al. (4). A systematic nomenclature of the isozymes of barley $\alpha$-amylase is suggested.

Abbreviations: EDTA $=$ ethylenediaminetetraacetic acid, disodium salt; HPLC $=$ high performance liquid chromatography; IEF = isoelectric focusing; $\mathrm{PAG}=$ polyacrylamide gel; 2-pe $=2$-pyridylethyl; $\mathrm{PTH}=$ phenylthiohydantoin; Tris = 2-amino-2(hydroxymethyl)-1,3-propandiol. 


\section{MATERIALS AND METHODS}

\subsection{Materials}

Commercial green malt ( 7 day germinated Hordeum vulgare L., cv. Gula) was obtained from the Carlsberg Malting Plants, Copenhagen. The lyophilized malt was ground in a grits mill (Brabender Quadrimat Junior) and used as the starting material for enzyme purification. Epoxy-Sepharose 4B and Phadebas blue starch tablets were from Pharmacia Fine Chemicals, Uppsala, Sweden. CM-52 Cellulose was from Whatman Ltd., Springfield, U.K. Ampholine PAG-plates ( $\mathrm{pH}$ 3.5-9.5) were from LKB, Bromma, Sweden. Bio-Gels P-6 and P-100 were obtained from Bio-Rad Laboratories, Richmond, CA. Cycloheptaamylose and oyster glycogen were from Sigma Chem. Co., St. Louis, MO. Reagents and solvents for chemical modifications, cleavages of peptide bonds, automated sequencing and reverse phase HPLC were as previously described $(26,27,28)$.

\subsection{Methods}

\subsubsection{Isolation of $\alpha$-amylases}

Proteins were extracted from malt and the amylases partially purified by glycogen precipitation and heat treatment as previously described $(16,22)$. The resulting supernatant was dialyzed overnight against elution buffer and the $\alpha$-amylase isozymes separated by chromatography on CM-cellulose. Alternatively, the malt extract was subjected to affinity chromatography on cycloheptaamylose-Sepharose as previously reported (24). The eluted $\alpha$-amylase isozymes were subsequently separated by $\mathrm{CM}$ cellulose chromatography.

\subsubsection{Preparation and purification of peptide} fragments from $\alpha$-amylases 1 and 2

$\alpha$-Amylase 1 was acetylated with acetic anhydride to block the primary amino groups (26). Acetyl- $\alpha$-amylase 1 and $\alpha$-amylase $2(5 \mathrm{mg} \times$ $\left.\mathrm{ml}^{-1}\right)$ were treated with hydroxylamine under previously described conditions $(2,28)$. After three hours the reaction mixtures were acidified and hydroxylamine and guanidinium chloride removed by gel filtration on Bio-Gel P-6.

Prior to cyanogen bromide cleavage $\alpha$-amy- lase 2 was dissolved in 7 M-guanidinium chloride, $0.2 \mathrm{M}$-Tris and $5 \mathrm{~mm}$-EDTA, $\mathrm{pH} 7.6(10 \mathrm{mg}$ $\left.\times \mathrm{ml}^{-1}\right)$, reduced with dithiothreitol $\left(4 \mathrm{mg} \times \mathrm{ml}^{-1}\right)$ and alkylated with 2 -vinylpyridine $\left(33 \mu \mathrm{l} \times \mathrm{ml}^{-1}\right)$ to yield 2-pe- $\alpha$-amylase $2(6,27)$. The 2-pe- $\alpha$ amylase 2 was treated with 2 -mercaptoethanol to reduce oxidized methionyl residues (9). Following lyophilization it was redissolved in $70 \%$ $(\mathrm{v} / \mathrm{v})$ trifluoroacetic acid $\left(20 \mathrm{mg} \times \mathrm{ml}^{-1}\right)$ containing cyanogen bromide $\left(20 \mathrm{mg} \times \mathrm{ml}^{-1}\right)$ and tryptamine hydrochloride $\left(7.5 \mathrm{mg} \times \mathrm{ml}^{-1}\right)$ and incubated as described (28). The lyophilized cleavage products were redissolved in $30 \%$ acetic acid (v/v) and gel filtered on Bio-Gel P-6 to remove tryptamine. The front pool of peptides was further fractionated on Bio-Gel P-100 (1.5 X $90 \mathrm{~cm}$ ) in $0.2 \mathrm{M}$-ammonium bicarbonate $\mathrm{pH} 7.8$ and a purified cyanogen bromide fragment was subfragmented using $\mathrm{S}$. aureus V8 protease as described (28). The second pool of peptides was subjected to reverse phase HPLC using a Wide Pore $\mathrm{C}_{18}$ column from J.T. Baker Research Products; elution was performed with a gradient of 2 to $50 \%(\mathrm{v} / \mathrm{v}) 1$-propanol in $0.1 \%$ trifluoroacetic acid $(\mathrm{v} / \mathrm{v})$ at a flow rate of $0.5 \mathrm{ml} \times \mathrm{min}^{-1}$ $(15,27,28)$.

\subsubsection{Analytical procedures}

$\alpha$-Amylase activity was assayed using Phadebas blue starch tablets. The isozymes were analytically separated by IEF as per the manufacturers' instructions (30). Amino acid compositions were determined as previously described (27). Tryptophan content was determined by second-derivative UV-spectroscopy (23) employing a Varian 2200 recording spectrophotometer. Automated sequencing was performed using a Beckman Model 890 C Sequencer (8) and the PTH-amino acids were identified by HPLC (25).

\section{RESULTS}

\subsection{Isolation and characterization of $\alpha$ - amylase 1 and 2}

The barley $a$-amylases were isolated as described in section 2.2.1. In small scale experiments (up to $10 \mathrm{mg}$ of each isozyme), heat 


\section{CMC FRACTIONS}

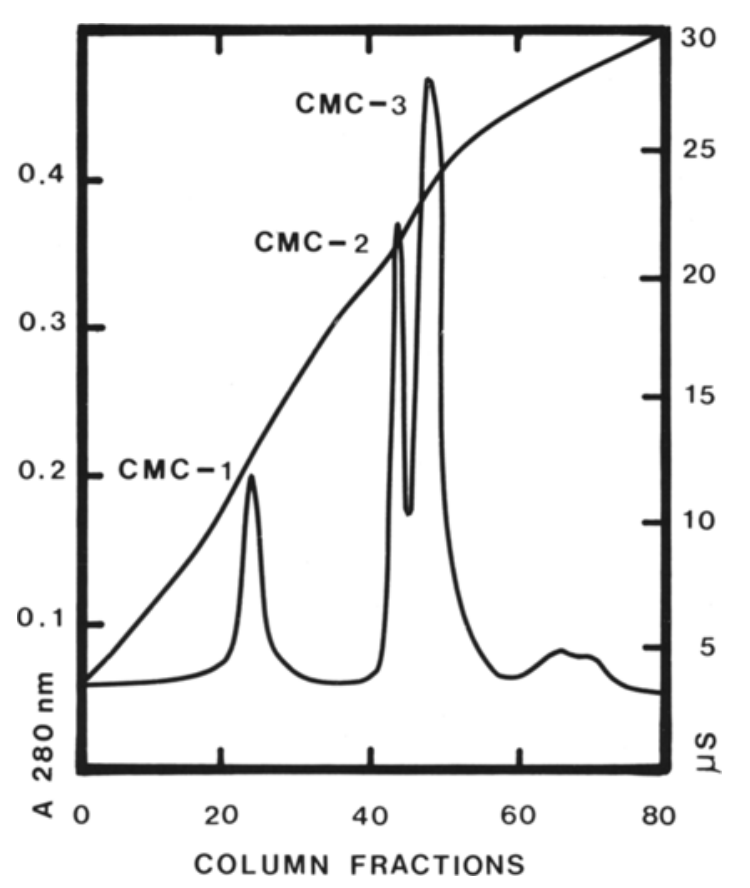

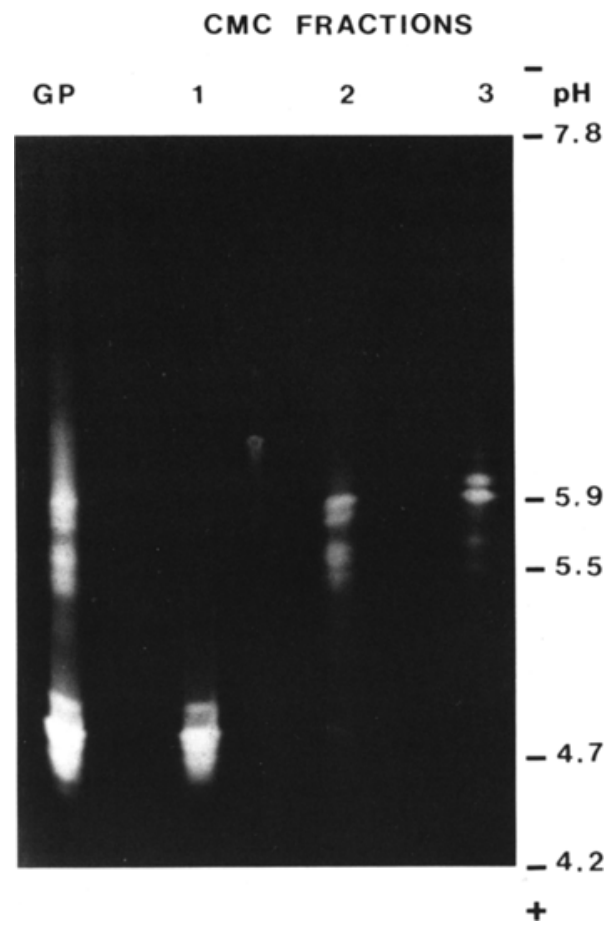

A

Figure 1. (A) CM-Cellulose cation exchange chromatography. A heat-treated, glycogen precipitate of barley malt extract was adsorbed to a $2.5 \times 10 \mathrm{~cm}$ column of Whatman CM- 52 cellulose equilibrated in $20 \mathrm{mM}$-sodium acetate (pH 4.75) and eluted with a zero to $250 \mathrm{~mm}-\mathrm{NaCl}$ gradient (in $20 \mathrm{~mm}$-sodium acetate, $\mathrm{pH} 5.1$ ). Fractions of $6 \mathrm{ml}$ were collected at a flow rate of $30 \mathrm{ml} \cdot \mathrm{hr}^{-1}$. The conductivity of column fractions in $\mu \mathrm{S}$ is shown. (B) IEF in Ampholine PAG-plates of GP (glycogen precipitate) and CM-cellulose column fractions 1, 2 and 3 as described in (A). Approximate $\mathrm{pH}$ values of areas of the IEF gel are shown at the right. A thousand Phadebas units were applied of each isozyme. The zymogram bands were developed as described by MUNDY et al. (16). $\alpha$-Amylase 1 corresponds to CMC-1 and $\alpha$-amylase 2 to CMC-2 and -3 , respectively.

treatment of the redissolved glycogen precipitate to remove $\beta$-amylase and the bifunctional $\alpha$ amylase/subtilisin inhibitor was easier and as effective as affinity chromatography on cycloheptaamylose-Sepharose (16). The elution pattern of $\alpha$-amylase isozymes on CM-cellulose (Figure 1A) resembles previously published results with barley malt $\alpha$-amylase isozymes 1 and 2 by MACGREGOR et al. (12-14). The isoelectric points for the $\alpha$-amylase 1 and 2 isozyme groups were about 4.65 and 5.90, respectively (Figure 1B). We have generally found that $\alpha$-amylase 1 (CMC-1, Figure 1A) appears as two or three bands in IEF, while $\alpha$-amylase 2 (CMC-2 and -3 ,
Figure 1A) consists of multiple bands. Similar patterns have been reported for $\alpha$-amylases from other barley cultivars $(7,12,14)$.

The amino acid compositions of the $\alpha$-amylase 1 and 2 preparations (Table I) clearly differed from each other only in their serine, alanine and methionine contents. The composition of $\alpha$-amylase 1 was very similar to that derived from the nucleotide sequence of a cloned $\alpha$-amylase cDNA by ROGERS and Milliman (20). However, our preparation had significantly higher contents of glutamine/glutamic acid and leucine. The amino acid composition of $\alpha$-amylase 2 (CMC-3, Figure 1A) resem- 
bled closely that of $\alpha$-amylase isolated by RODAWAY (19) from gibberellic acid treated Himalaya barley seeds. The concentration of gibberellic acid in that study favoured the synthesis of the high pI group of isozymes (7). Only minor differences existed between the amino acid compositions of the forms of $\alpha$-amylase 2 in CMC-2 (not shown) and CMC-3 (Figure 1A). The protein in CMC-3 was used for protein sequencing (section 3.3). We found that $\alpha$-amylase 2 contains 3 half-cystines (Table I), while 4 residues have been deduced from the nucleotide sequence of cDNA corresponding to the $\alpha$-amylase 1 isozyme (20).

\subsection{Partial sequence determination of a-amylase 1}

The $\mathrm{NH}_{2}$-terminal sequence of $\boldsymbol{\alpha}$-amylase 1 isolated in the present study was found to be
His-GIn-Val-Leu-Phe-Gln-Gly-Phe-Asn-Trpin agreement with results reported for this isozyme isolated from Himalaya barley (4) and derived by ROGERS and MILLIMAN from a cloned $\mathrm{CDNA}$ originating from the same source (20). Hydroxylamine treatment of the $\mathrm{NH}_{2}$-terminally blocked acetyl- $\alpha$-amylase 1 resulted in appearance of a fragment having the $\mathrm{NH}_{2}$-terminal sequence Gly-Ile-Thr-Ala-Thr-Ser-AlaLeu-Lys-Ile- in agreement with cleavage of the Asn(370)-Gly(371) peptide bond in the protein sequence deduced from cDNA (20).

\subsection{Partial sequence determination of $\alpha$-amylase 2}

Our $\alpha$-amylase 2 preparation (CMC-3, Figure 1A) had a blocked $\mathrm{NH}_{2}$-terminus as reported by CHANDLER et al. for the corresponding enzyme

Table I

Amino acid composition" of barley malt $\alpha$-amylases

\begin{tabular}{|c|c|c|c|c|}
\hline & $\begin{array}{l}\alpha \text {-Amylase } 1 \\
\text { (this study) }\end{array}$ & $\begin{array}{l}\text { a-Amylase } 1^{\mathrm{b}} \\
\text { (Rogers \& Milliman (20)) }\end{array}$ & $\begin{array}{l}\alpha \text {-Amylase } 2^{\text {c) }} \\
\text { (this study) }\end{array}$ & $\begin{array}{l}\text { a-Amylase } \\
\text { (RoDAWAY (19)) }\end{array}$ \\
\hline Aspartic acid & 50 & 54 & 52 & 49 \\
\hline Threonine & 18 & 17 & 17 & 16 \\
\hline Serine & 25 & 21 & 14 & 14 \\
\hline Glutamic acid & 35 & 25 & 30 & 27 \\
\hline Proline & 18 & 17 & 19 & 20 \\
\hline Glycine & 44 & 44 & 46 & 46 \\
\hline Alanine & 46 & 47 & 35 & 33 \\
\hline Valine & 28 & 28 & 25 & 22 \\
\hline Methionine & 12 & 12 & 6 & 7 \\
\hline Isoleucine & 23 & 23 & 23 & 17 \\
\hline Leucine & 32 & 25 & 28 & 25 \\
\hline Tyrosine & 15 & 16 & 15 & 14 \\
\hline Phenylalanine & 16 & 15 & 16 & 17 \\
\hline Histidine & 13 & 13 & 16 & 16 \\
\hline Half-cystine & - & 4 & $3^{\mathrm{e})}$ & - \\
\hline Lysine & 21 & 22 & 22 & 22 \\
\hline Arginine & 15 & 15 & 17 & 17 \\
\hline Tryptophan & - & 16 & $16^{13}$ & - \\
\hline
\end{tabular}

al Number of residues per molecule

"Residues 1-24 (leader sequence) deduced from the cDNA sequence have been omitted

c) From CMC-3 (Figure 1A)

d) Presumably this is mainly $\alpha$-amylase 2, see text for further explanation

"As 2-pyridylethylcysteine

"By second-derivative UV-spectroscopy 
from Himalaya barley (4). Separation of the products obtained by hydroxylamine cleavage of $a$-amylase 2 led to two peptide fractions (Figure 2). Sequencing of the front pool confirmed the deduced sequence (4) from Gly $(40)$ to Tyr(82)(Figure 4). The second pool (B, Figure 2) was purified by reverse phase HPLC. Its major peptide fragment had an amino acid composition (Table II) matching Gln(26)-Asn(40) (4), suggesting that the blocked $\mathrm{NH}_{2}$-terminus of $\alpha$-amylase 2 is a pyroglutamic acid residue. This residue is therefore the site of peptidase cleavage removing the leader sequence in the translation product of the mRNA corresponding to the cloned cDNA. The $\mathrm{NH}_{2}$-terminal His in $\alpha$-amylase 1 is found at position 25 (20) one residue ahead of the terminus suggested for $\alpha$-amylase 2 .

$\alpha$-Amylase 2 contained only 6 methionines (Table I). Fragments of $\alpha$-amylase 2 , obtained by cyanogen bromide cleavage were separated by gel filtration on Bic-Gel P-6 into two pools of peptides (Figure 3). In Figure 4 are shown the peptide sequences starting by Gly(49), Pro(78), Ile(148), Trp(323) and GIn(332) (numbering according to CHANDLER et al. (4)) that were identified by $\mathrm{NH}_{2}$-terminal sequencing of the pool of larger peptides (A, Figure 3). The long fragment Ile(148)-Hse(299) was also sequenced after purification from pool $A$ by gel filtration on Bio-Gel P-100 (section 2.2.2). A subfragment of Ile(148)-Hse(299), obtained by digestion with $S$. aureus V8 protease, was purified by reverse phase HPLC. Its amino acid composition (Table II) corresponds to Ile(230)-Glu(252) (Figure 4).

The cyanogen bromide fragment Gly(49)Hse(77) was sequenced in its full length by the identification of the $42 \mathrm{NH}_{2}$-terminal residues of the hydroxylamine fragment of $\alpha$-amylase 2 starting with residue Gly(41) (Figure 4). Two smaller fragments identified as the $\mathrm{NH}_{2}$-terminal fragment $\mathrm{GIn}(26)$-Hse(48) and the fragment lle(300)-Hse(322) were purified by reverse phase HPLC of pool B seen in Figure 3. The former fragment had a blocked $\mathrm{NH}_{2}$-terminus. The $\mathrm{NH}_{2}$-terminal sequence of fragment Ile(300)-Hse(322) (Figure 4) and the amino acid compositions of both fragments (Table II) agree with the nucleotide sequence data of the pHV19 clone of CHANDLER et al. (4). Comparison of the amino acid composition of the cyanogen bromide fragment eluting at 21\% 1-propanol (Table II) with the cDNA sequence (4) again suggested

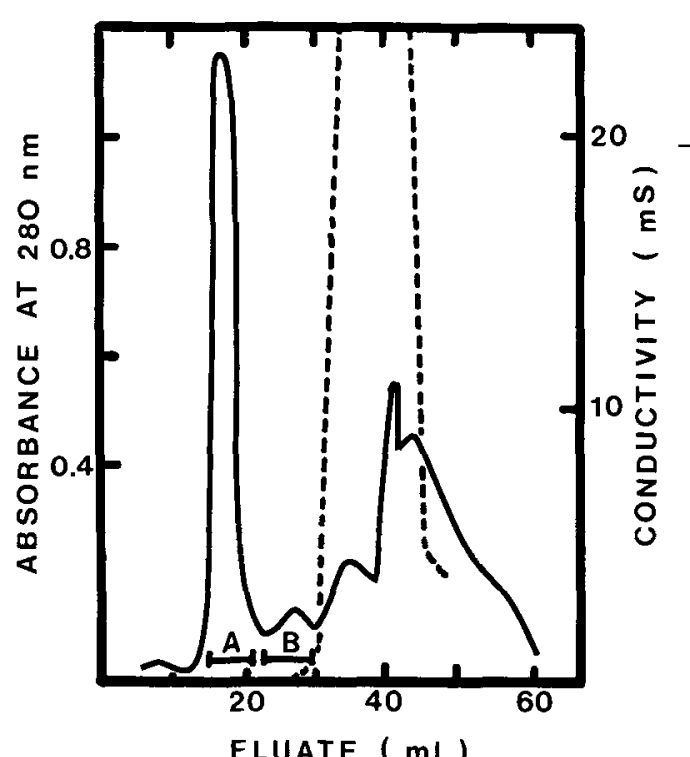

Figure 2. Gel filtration of hydroxylamine reaction mixture from $\alpha$-amylase 2 ( $3 \mathrm{mg}$ ) on Bio-Gel P-6 (0.9 $\times 30 \mathrm{~cm}$ ) eluted with $30 \%$ acetic acid. $\mathrm{E}_{280}(-)$, conductivity (--_-).

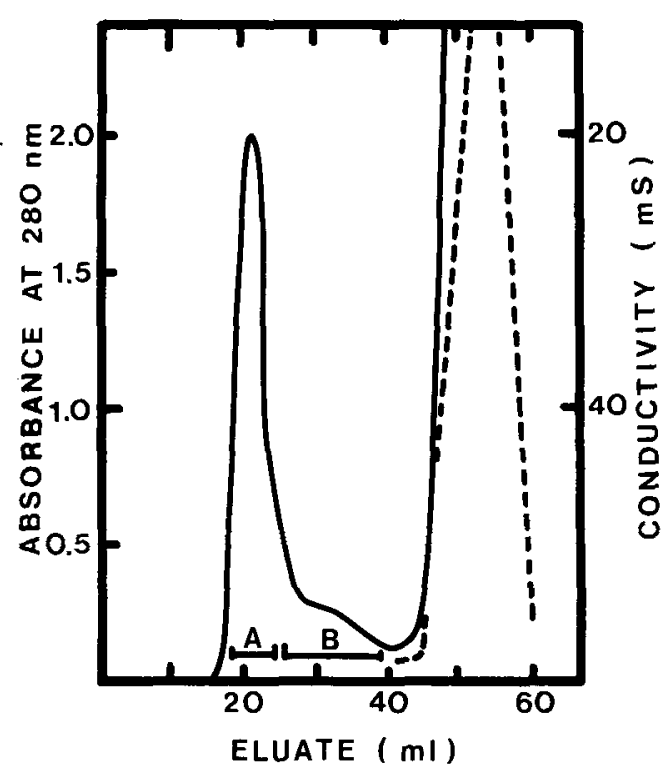

Figure 3. Gel filtration of cyanogen bromide fragments $(6 \mathrm{mg})$ from $\alpha$-amylase 2 on Bio-Gel P- $6(0.9 \times 30$ $\mathrm{cm})$ eluted with $30 \%$ acetic acid. $\mathrm{E}_{280}(-)$, conductivity (----). 
Table II

Amino acid compositions" of peptide fragments from 2-pe- $\alpha$-amylase 2 isolated by reverse phase HPLC

\begin{tabular}{|c|c|c|c|c|c|c|c|c|}
\hline \multirow[b]{3}{*}{ Aspartic acid } & \multicolumn{4}{|c|}{$\begin{array}{l}\text { Cyanogen bromide } \\
\text { fragments }\end{array}$} & \multirow{2}{*}{\multicolumn{2}{|c|}{$\begin{array}{l}\text { S.aureus V8 } \\
\text { protease fragment } \\
\text { Ile(230)- } \\
\text { Glu(252) }\end{array}$}} & \multirow{2}{*}{\multicolumn{2}{|c|}{$\begin{array}{l}\begin{array}{l}\text { Hydroxylamine } \\
\text { fragment }\end{array} \\
\text { Gln(26)- } \\
\text { Asn(40) }\end{array}$}} \\
\hline & \multicolumn{2}{|c|}{$\begin{array}{l}\text { Ile(300)- } \\
\text { Hse(322) }\end{array}$} & \multicolumn{2}{|c|}{$\begin{array}{l}\mathrm{Gln}(26)- \\
\mathrm{Hse}(48)\end{array}$} & & & & \\
\hline & 2.6 & (3) & 3.0 & (3) & 3.9 & (4) & 2.0 & (2) \\
\hline Threonine & 2.6 & (3) & 0.3 & (0) & 0.9 & (1) & & \\
\hline Serine & 1.2 & (1) & 1.1 & (1) & 1.3 & (1) & 1.0 & (1) \\
\hline Glutamic acid & 1.2 & (1) & 2.9 & (3) & 3.3 & (4) & 3.0 & (3) \\
\hline Proline & 0.8 & (1) & 0.2 & (0) & 1.2 & (1) & & \\
\hline Glycine & 2.3 & (2) & 2.8 & (3) & 2.8 & (3) & 1.2 & (1) \\
\hline Alanine & 2.0 & (2) & 1.2 & (1) & & & & \\
\hline Valine & 1.7 & (2) & 1.0 & (1) & 0.3 & (0) & 0.8 & (1) \\
\hline Homoserine & + & (1) & 0.6 & (1) & & & & \\
\hline Isoleucine & 1.1 & (1) & 0.3 & (0) & 1.2 & (1) & & \\
\hline Leucine & 0.3 & (0) & 2.0 & (2) & 2.4 & (2) & 1.3 & (1) \\
\hline Tyrosine & 0.9 & (1) & 0.9 & (1) & & & & \\
\hline Phenylalanine & 0.8 & (1) & 2.5 & (3) & 1.9 & (2) & & \\
\hline Histidine & 1.6 & (2) & 0.9 & (1) & 1.0 & (1) & 0.8 & (1) \\
\hline Lysine & 1.0 & (1) & 0.9 & (1) & 1.2 & (1) & 1.0 & (1) \\
\hline Arginine & 0.3 & (0) & 1.1 & (1) & & & & \\
\hline Tryptophan ${ }^{c)}$ & 2.1 & (2) & 2.6 & (3) & 0.8 & & 2.2 & (2) \\
\hline Elution conditions" & 15 & & & & & & & \\
\hline
\end{tabular}

a) Number of residues per fragment.

b) The first gradient was followed by elution with a linear gradient from 40 to $80 \%$ 1-propanol over $30 \mathrm{~min}$.

c) Determined by UV-spectroscopy using $\varepsilon_{280}$-values $=5500 \mathrm{M}^{-1} \times \mathrm{cm}^{-1}$ and $1450 \mathrm{M}^{-1} \times \mathrm{cm}^{-1}$ for a tryptophanyl and a tyrosyl residue, respectively.

d) 1-Propanol concentration (\%, vol/vol) at the elution position.

The values in parenthesis and the numbering are from CHANDLER et al. (4). The fragments were obtained as described in the text.

that $\alpha$-amylase 2 has a pyroglutamyl group at the $\mathrm{NH}_{2}$-terminus, as seen also for two mammalian $\alpha$-amylases $(10,11)$. The sequence from $\operatorname{Trp}(323)$ through $\operatorname{Met}(331)$ into the fragment starting with $G \ln (332)$ (Figure 4) was observed among the larger cyanogen bromide fragments (in pool A, Figure 3) indicating that the peptide bond $\operatorname{Met}(331)-G \ln (332)$ was incompletely cleaved.

\section{DISCUSSION}

The positions of all of the residues we have sequenced in $\alpha$-amylase 2 (about $30 \%$ of the molecule) and the composition of isolated, apparently homogeneous peptide fragments (representing another $12 \%$ of the molecule) agree exactly with the amino acid sequence informa- tion derived from the partial-length $\mathrm{cDNA}$ clone by CHANDLER et al. (4). We have no evidence that multiple forms of $\alpha$-amylase 2 seen in isoelectric focusing experiments (Figure 1B; 3, 7, 12) differ in amino acid sequences. Recent studies by ROGERS and Milliman (21), however, indicate that a multigene family exists for $a$-amylase 1 with at least two active members represented by different transcripts. This is presumably the case also for multiple $\alpha$-amylase 2 forms as has been suggested from both peptide mapping experiments $(3,7)$ and mapping of $\alpha$-amylase structural genes with cDNA probes (18).

To summarize, $\alpha$-amylase 1 isolated in this study corresponds to clone $E$ of ROGERS and MiLliman $(20,21)$ which thus represents one of 


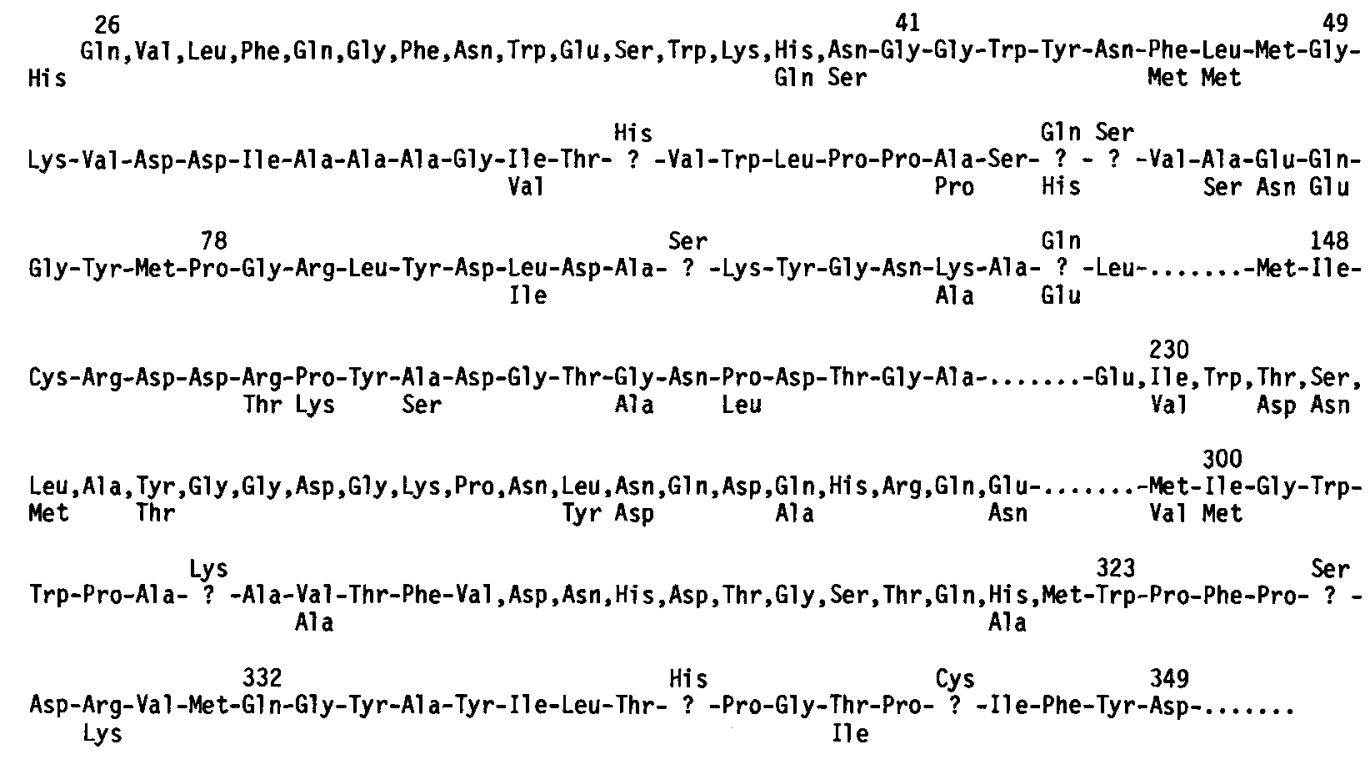

Figure 4. Amino acid residues identified by peptide sequencing of fragments from $\alpha$-amylase 2 from barley malt. The numbering is according to CHANDLER et al. (4). Since the protein has a blocked $\mathrm{NH}_{2}$-terminus the GIn at position 26 is suggested to cyclize to yield a pyroglumate residue. Residues indicated below the continuous sequence are derived for the homologous $\alpha$-amylase 1 from a cloned cDNA by ROGERS and MiLLIMAN (19). Residues indicated above the continuous sequence were deduced from the nucleotide sequence of cloned $\alpha$-amylase 2 cDNA (4). Residues separated by commas are written as deduced by CHANDLER et al. (4) and have been confirmed in the present work only by amino acid compositions of isolated peptides (Table II).

the low $\mathrm{pI}$ isozymes. The protein sequence data for $\alpha$-amylase 2 , a high pI isozyme, showed that it corresponds to the partial-length $\alpha$-amylase cDNA clone pHV 19 described by CHANDLER et al. (4) and thus most probably also to the clone 103 characterized by MUTHUKRISHNAN et al. $(17,18)$. In the literature the low and high pl isozymes have been designated respectively by 1 and 2 (12-14). Other workers named them the group $A$ and $B$ isozymes $(4,7)$ specified by the $\alpha$-Amy 2 and $\alpha$-Amy 1 loci (1). To avoid this confusing terminology, we suggest that the barley malt $\alpha$-amylase isozymes in future be numbered 1 and 2 according to the rules of IUPACIUB nomenclature (31) which recommend that further anodically migrating forms, i.e. those of lowest pI, be designated by the lower number.

\section{ACKNOWLEDGEMENTS}

We are indebted to Dr. J.C. Rogers, Washington University School of Medicine, St. Louis, $\mathrm{MO}$, for information on the sequence of $\alpha$-amylase 2 cDNA. Professor MARTIN OtTESEN and
Fil.dr. LARS MUNCK are gratefully acknowledged for their support of this work and critical review of the manuscript. Mss ANNETTE HANSEN, EDITH FløISTRUP, BODIL CORNELIUSSEN, LONE SøRENSEN and PIA BREDDAM are thanked for their excellent technical assistance. Professor DITER VON WETTSTEIN, the Department of Physiology, Carlsberg Laboratory, is thanked for the use of the Varian 2200 spectrophotometer.

\section{REFERENCES}

1. BRoWN, A.H.D. \& J.V. JACOBSEN: Genetic basis and natural variation of $\alpha$-amylase isozymes in barley. Genet. Res. Camb. 40, 315-324 (1982)

2. Bornstein, P.\& G. Balian: Cleavage at Asn-Gly bonds with hydroxylamine. Meth. Enzymol. 47, 132-145 (1977)

3. CALLIS, J.\& T.-H.D. Ho: Multiple molecular forms of the gibberellin-induced $a$-amylase from the aleurone layers of barley seeds. Arch. Biochem. Biophys. 224, 224-234 (1983)

4. Chandler, P.M., J.A. ZWAR, J.V. JACOBSEN, 
T.J.V.HIGGINS \& A.S. INGLIS: The effects of gibberellic acid and abscisic acid on $\alpha$-amylase mRNA levels in barley aleurone layers studies using an $\alpha$-amylase cDNA clone. Plant Mol. Biol. 3, 407418 (1984)

5. Chrispeels, M.J.\&J.E. VARNer: Gibberellic acidenhanced synthesis and release of $\alpha$-amylase and ribonulease by isolated barley aleurone layers. Plant Physiol. 42, 398-406 (1967)

6. Friedman, M., J.C. Zahnley \& J.R. WaGneR: Estimation of the disulfide content of trypsin inhibitors as S- $\beta$-(2-pyridylethyl)-L-cysteine. Anal. Biochem. 106, 27-34 (1980)

7. JACOBSEN, J.V. \& T.J.V. Higgins: Characterization of the $\alpha$-amylases synthesized by aleurone layers of Himalaya barley in response to gibberellic acid. Plant Physiol. 70, 1647-1653 (1982)

8. Johansen, J.T., C. Overballe-Petersen, B. Martin, V. HaSemanN \& I. SVENDSEN: The complete amino acid sequence of copper, zinc superoxide dismutase from Saccharomyces cerevisiae. Carlsberg Res. Commun. 44, 201-217 (1979)

9. Jori. G., G. Galiazzo, A. Marzotto \& E. ScofFONE: Selective and reversible photo-oxidation of methionyl residues in lysozyme. J. Biol. Chem. 243, 4272-4278 (1968)

10. Karn, R.C., T.E. Petersen, J.P. HJort, J.T. NielSEN \& P. ROEPSTORFF: Characterization of the amino termini of mouse salivary and pancreatic amylases. FEBS Letters 126, 242-246 (1981)

11. KLUH, I.: Amino acid sequence of hog pancreatic $\alpha$-amylase isoenzyme I. FEBS Letters 136, 231-234 (1981)

12. MACGRegor. A.W.: Isolation, purification and electrophoretic properties of an $\alpha$-amylase from malted barley. J. Inst. Brew. 83, 100-103 (1977)

13. MacGregor, A.W: Changes in $a$-amylase enzymes during germination. J. Am. Soc. Brew. Chem. 36, 1-55 (1978)

14. MacGregor, A.W., D.E. LaBerge \& W.O.S. MeREDITH: Separation of $\alpha$ - and $\beta$-amylase enzymes from barley malt by ion exchange chromatography. Cereal. Chem. 48, 490-498 (1971)

15. MAHONEY, W.C.\& M.A. HERMODSON: Separation of large denatured peptides by reverse phase high performance liquid chromatography. Trifluoroacetic acid as a peptide solvent. J. Biol. Chem. 255, 11199-11203 (1980)

16. Mundy, J., I. Svendsen \& J. HejgaARd: Barley $\alpha$-amylase/subtilisin inhibitor. 1. Isolation and characterization. Carlsberg Res. Commun. 48, 81-90 (1983)

17. Muthukrishnan, S.,G.R.Chandra \& E.S.MaXWELL: Hormonal control of $\alpha$-amylase gene expression in barley. Studies using a cloned cDNA probe. J. Biol. Chem. 258, 2370-2375 (1983)

18. Muthukrishnan, S., B.S. Gill, M. Swegle \& G.R. ChANDRA: Structural genes for $\alpha$-amylases are located on barley chromosomes 1 and 6 . J. Biol. Chem. 259, 13637-13639 (1984)

19. Rodaway, S.J.: Composition of $\alpha$-amylase secreted by aleurone layers of grains of Himalaya barley. Phytochemistry 17, 385-389 (1978)

20. RoGers, J.C. \& C. Milliman: Isolation and sequence analysis of a barley $\alpha$-amylase cDNA clone. J. Biol. Chem. 258, 8169-8174 (1983)

21. Rogers, J.C.\& C. Milliman: Coordinate increase in major transcripts from the high $\mathrm{pI} \alpha$-amylase multigene family in barley aleurone cells stimulated with gibberellic acid. J. Biol. Chem. 259, 12234-12240 (1984)

22. Schramm, M. \& A. Loyter: Purification of $\alpha$ amylases by precipitation of $\alpha$-amylase-glycogen complexes. Meth. Enzymol. 8, 533-537 (1966)

23. Servillo. L., G. Colonna, C. Balestrieri, R. RAGONE\& G. IRACE: Simultaneous determination of tyrosine and tryptophan residues in proteins by second-derivative spectroscopy. Anal. Biochem. 126, 251-257 (1982)

24. Silvanovich, M.P. \& R.D. Hill: Affinity chromatography of cereal $\alpha$-amylase. Anal. Biochem. 73 , 430-433 (1976)

25. Svendsen, I., B. Martin \& I. Jonassen: Characteristics of Hiproly barley III. Amino acid sequences of two lysine-rich proteins. Carlsberg Res. Commun. 45, 79-85 (1980)

26. Svensson, B., T.G. Pedersen, I. Svendsen, T. SAKAI \& M. OTtesEN: Characterization of two forms of glucoamylase from Aspergillus niger. Carlsberg Res. Commun. 47, 55-69 (1982)

27. SvensSon, B., K. LARSEN \& I. SvendSEN: Amino acid sequence of tryptic fragments of glucoamylase Gl from Aspergillus niger. Carlsberg Res. Commun. 48, 517-527 (1983)

28. Svensson, B., K. LarSen, I SVendsen \& E. Boel: The complete amino acid sequence of the glycoprotein, glucoamylase $\mathrm{Gl}$, from Aspergillus niger. Carlsberg Res. Commun. 48, 529-544 (1983)

29. VARNER,J.E. \& G.R. ChANDRA: Hormonal control of enzyme synthesis in barley endosperm. Proc. Natl. Acad. Sci. 52, 100-106 (1964)

30. WINTER, A., K. EK \& U.-B. ANDERSSON: Analytical electrophocusing in thin layers of polyacrylamide gels. LKB Application note 250

31. Enzyme Nomenclature, Recommendations (1972) of IUPAC-IUB (Elsevier Scientific Publishing Company, Amsterdam)

Accepted by:

H. KLENOW, E. LuND and S.O. ANDERSEN 